\title{
To inhabit the twelve i pamawen of Taguelzi: fortified dwellings as alive ruins in the Gourara (Algerian Sahara)
}

\section{Illili Mahrour}

Laboratoire d'Anthropologie Des Enjeux Contemporains (FRE 2002) - Université Lumière Lyon 2 - École Normale Supérieure de Lyon, Lyon, France, illilimg@yahoo.fr

\begin{abstract}
In the southwest of the Algerian Sahara, Taguelzi is one of the fortified settlement oases forming the network of the Gourara defensive structures situated on the southern edge of the Ouled Aïssa Hmada. It is a large and long flat limestone area, which borders, from north to south, the west side of the Timimoun sebkha. Despite its position on the periphery of Charouine, one of the Gourara sub-region main human settlement, Taguelzi is exactly situated at the crossroads of ancient caravan routes linking sub-Saharan Africa to the Atlantic shores and the Mediterranean world through both the Messaoura wadi and the shortcut to Figuig in Morocco, across the Great Western Erg. Taguelzi strategic position, on the southern cornice of the Ouled Aïssa hamada facing the north of Moulay Mohemmed Erg, an arm of the Great Western Erg, allows to reach the Aougrout, the main sub region of the Gourara, through the Deldoul sub region in few hours, and eventually from there to get to the Gourara main cities.

By using a space anthropological approach based on spatiality vocabulary, we have tried to understand this Saharan settlement formed by twelve distinct defensive inhabited structures and why some of them are considered as "dead ruins" and others as still "alive ruins". Taguelzi twelve fortified inhabited structures reported through "the spatiality living word" reveals the living space organization complexity at the territory scale and may explain the morphogenesis of those defensive structures which gave birth to troglodyte habitat, to stone defensive towers and double walled fortifications with gardens, wells, water system irrigation and wide-open cemeteries. Today, despite unsuccessful state rehabilitation projects and the fortifications advanced state of ruins after the 2008 devastating floods, the inhabitants still clearly identify and refer to them as the twelve "i yamawen of Taguelzi".
\end{abstract}

Keywords: I ramawen, fortified habitat, alive ruins, stone architecture.

\section{Introduction}

In the south west of the Algerian Sahara, Taguelzi is one of the fortified settlement oases forming the network of the Gourara defensive structures situated on the southern edge of the Ouled Aïssa Hmada. It is a large and long flat limestone area, which borders, from north to south, the west side of the Timimoun sebkha. Despite its position on the periphery of Charouine, one of the Gourara sub-region main hu- man settlement, Taguelzi is exactly situated at the crossroads of ancient caravan routes linking sub-Saharan Africa to the Atlantic shores and the Mediterranean world through both the Messaoura wadi and the shortcut to Figuig in Morocco, across the Great Western Erg. 


\subsection{To inhabit Taguelzi}

Taguelzi strategic position, on the southern cornice of the Ouled Aïssa Hmada facing the north of Moulay Mohemmed Erg, an arm of the Great Western Erg, allows to reach the Aougrout, the main sub region of the Gourara, through the Deldoul sub region in few hours, and eventually from there to get to the Gourara main cities. As the geographer Bisson points out, "this site, on the edge of the Hamadan cornice an excellent defensive landmark- lost its interest in the 1950s, as it was preferable (for inhabitants) to move closer to the palm grove below; today it is given importance, thanks to its promontory position nearby the road connecting Béchar to Timimoun” (Bisson, Jarir, 2002).

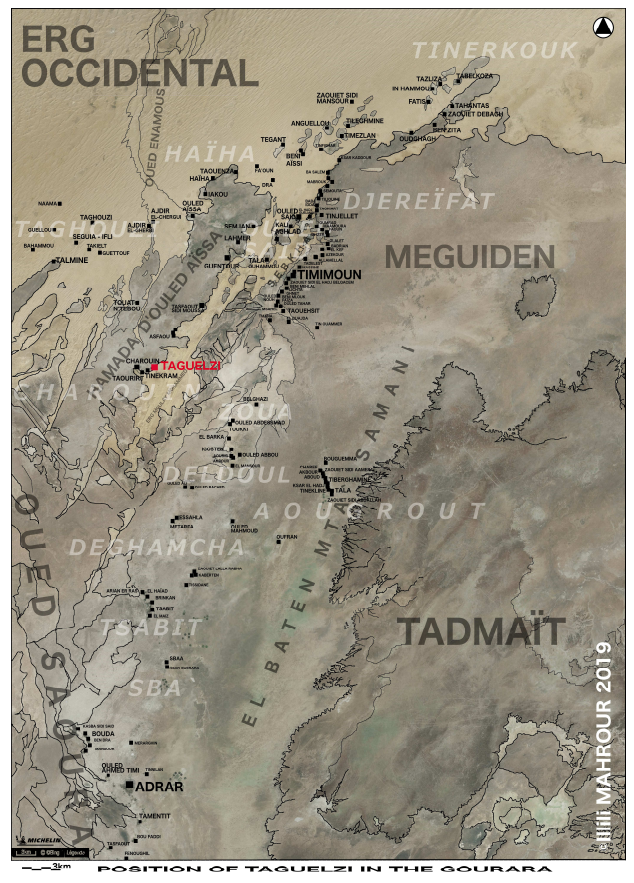

Fig. 1. Taguelzi situation in the Gourara region (Illili Mahrour, 2019).

The geographical configuration of the Ouled Aïssa Hmada southern side favoured the gradual establishment of seven fortified human settlements forming, in the nineteenth century, the Charouin district: Charouin (Ksar El kebir), Kasba El Arbi, Kasba El Kedima, Kasba El Chorfa, Oulad Hammou, Tinkran and Taguelzi
(De Colomb, 1860). Today, this alignment represents a discontinuous network of 36 fortifications, mostly in ruins, composed of six ksour, over a distance of about $30 \mathrm{~km}$ from north to south: Tasfaout Sidi Moussa, Asfaou, Taguelzi, Tinkram, Taourirt and Charouin.

The Ouled Aïssa Hmada is a silicified limestone slab strongly karstified with a millstone often used in the fortification's walls and towers. The base of the cornice is made of the Continental Intercalaire layers and the summit is a silicified limestone slab (Bisson, 1957). Dayas, few meters sinkholes in diameter, characterize this hamada and identify the area where the inhabitants started to dig the iflan galleries to bring water down to the gardens.

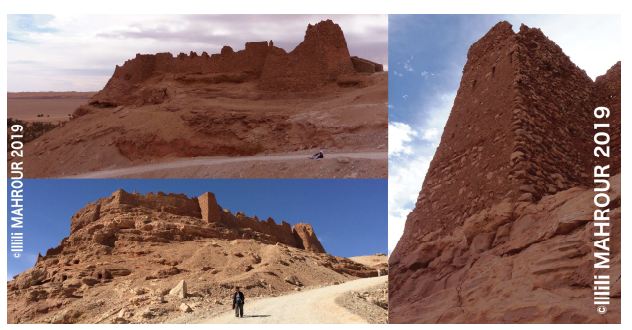

Fig. 2. Agham At Moussa Ouhammou, Taguelzi (Illili Mahrour, 2018).

In Taguelzi, water appears in various ways: iflan and wells in the gardens and the fortresses. The wells are built in worked stone masonry when they are in the gardens and are dug in the rock inside the fortresses. Today, we still find three wells in Agham At Moussa Ouhammou, one in Taghamt Anoura' and one outside Izendha'.

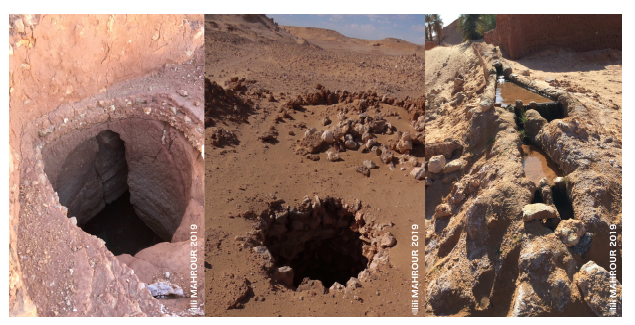

Fig. 3. Worked stone masonry wells and Ifli in Taghamt Enoura' and Izendha', Taguelzi (Illili Mahrour, 2018).

In Taguelzi, the ifli is a water supply and distribution system characterized by kilometres of 
tunnels dug in the hamada to capture and channel irrigation water. The galleries dug into the rocks are still visible on the surface thanks to the alignment of series of "wells-chimneys", which favour condensation to optimize water flow (Laureano, 1991). Water in the palm grove gardens is shared through taheleft, a stone distributing comb, on a pro rata of the work provided to build the seven main iflan (foggarates): Ifli n'Abdallah Ouyahya, Ifli n'Youssef Ou`athmane, Ifli n'Assba`i, Ifli n'Djerda, Ifli n'Che bet, Ifli n'Ighzamqan, Ifli n'Emkoudas and Ifli n'Izidi` (Fig. 4).

Today, a modern concrete water tower provides water to the inhabitants, but it is combined with the iflan water supply for the garden's irrigation. The morphogenesis of the Saharan urban fabric was structured by the iflan layout, which induced the spatial distribution of both the fortresses positioning, and the palm plantation gardens parcel system (Mahrour, 1992). In Taguelzi, the wells and the carried water have made easier the establishment of fourteen ancient fortified human settlements on various positions: thirteen have an implementation on the limestone silicified plateau edges and the fourteenth is located lower on a second silicified limestone slab taken in the soft sandstone mass in the gardens. The inhabitants identify several specific places marking Taguelzi inhabited space. Each place corresponds to a space practice or identifies a landscape marker as timedwel which refers to a precise area in the palm grove where an appreciated variety of palm trees called timedwell are grown.

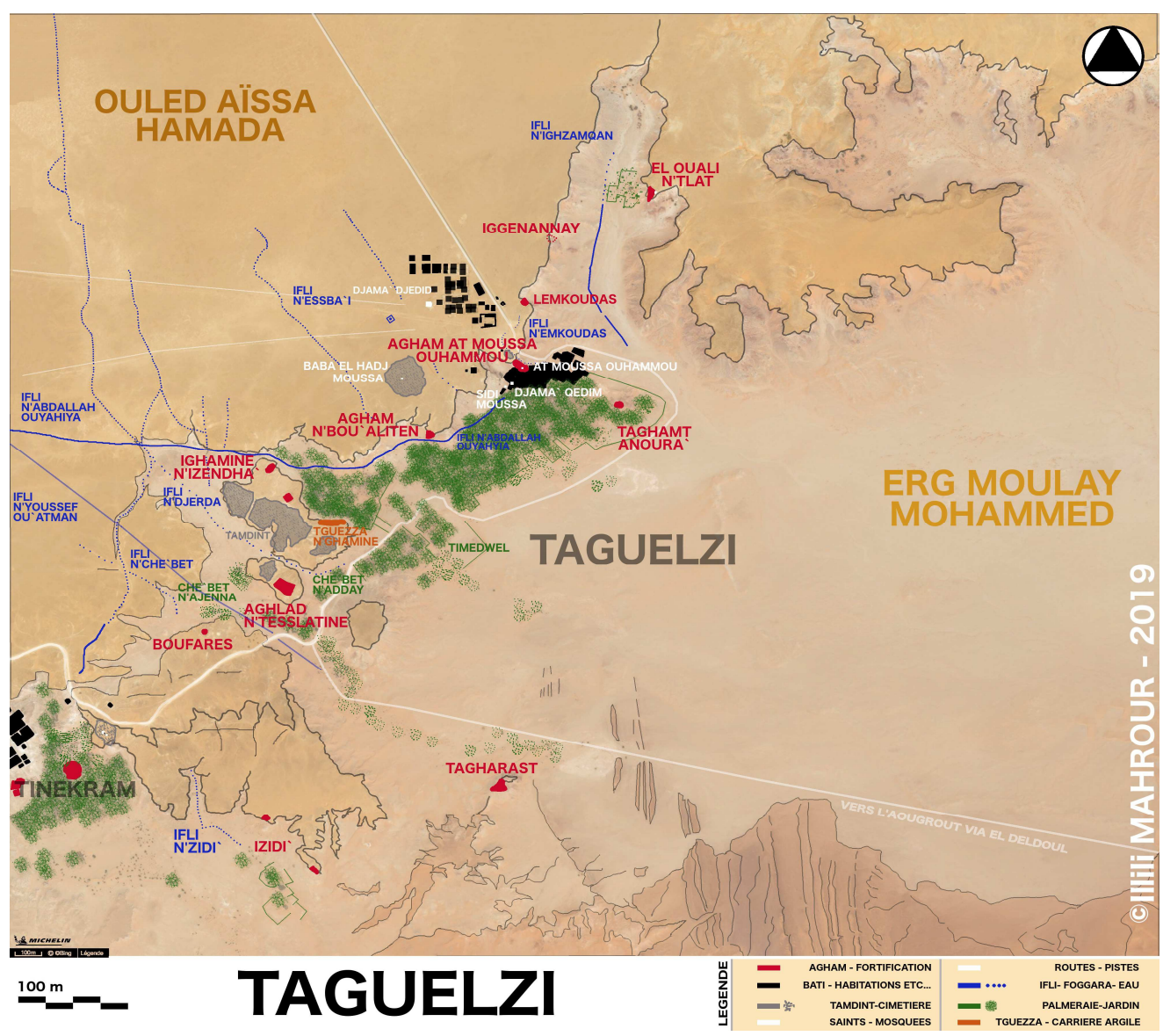

Fig. 4. Taguelzi inhabited space (Illili Mahrour, 2019). 


\section{Taguelzi twelve i pamawen: dead or alive ruins?}

The analysis of Taguelzi site raises several questions about its spatial occupation strategy. Obviously, the rocky peaks were occupied as a defensive place but a spatial complexity is read on the territory scale in a complementary relationship between neighbouring cities. Nevertheless, to resort to the inhabitant's knowledge introduces an invisible dimension that of the place practices in time and space. During our various field surveys, we were lucky to meet the fortresses dwellers descendants who introduced us to their space practices during a working session based on an aerial photo of Taguelzi (Google Earth). They told us the different legends and founding myths of Taguelzi and positioned the fourteen fortresses on the territory by bringing spatial and architectural new precisions to each one.

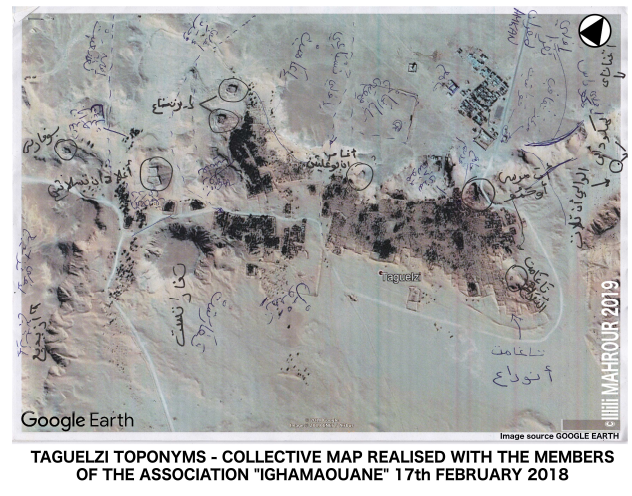

Fig. 5. Taguelzi collective map. (Illili Mahrour, 2019).

By using a space anthropological approach based on spatiality vocabulary we have tried to understand this Saharan settlement formed by fourteen distinct defensive inhabited structures and why some of them are considered as "dead ruins" and others as still "alive ruins". Taguelzi fortified inhabited structures reported through "the spatiality living word" reveals the living space organization complexity at the territory scale and may explain the morphogenesis of those defensive structures which gave birth to troglodyte habitat, to stone defensive towers and double walled fortifications with gardens, wells, water system irrigation and wide-open cemeteries.

Today, despite unsuccessful state rehabilitation projects and the fortifications advanced state of ruins after devastating floods, the inhabitants still clearly identify and refer to them as the twelve "iramawen of Taguelzi".

\subsection{Taguelzi toponymy and founding myths}

The study of place names, their origins, meanings and specific uses contributes to the understanding of the living interactions with the existing building (Villanova, Duarte, 2012), here, the Taguelzi 12 iyamawen. During our surveys, we had the chance to meet one of the old women still inhabiting there who confirmed the information collected in the field, that the toponym "Taguelzi" is not a Berber or Arabic word but refers to the British arrival in this region. Historically, we have no record of English military presence or conquest in the Gourara, but we were able to confirm this information on a manuscript sheet, written in 1826, that mentions the arrival of British traders in the neighbouring Touat region coming from Ghadames, in 1631 (Martin, 1923). The exceptional nature of this event echoed in this toponym, can possibly contribute to the explanation of the large number of iramawen.

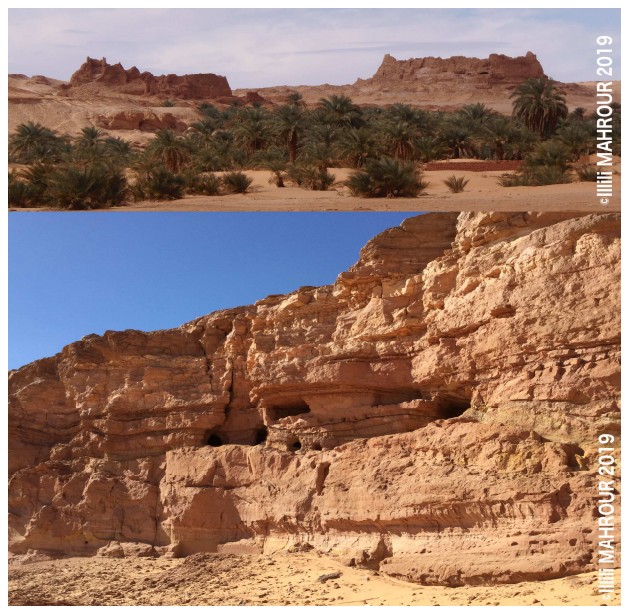

Fig. 6. The fortresses of Ighamine n'Izendha' and Agham n'Bou'liten, Taguelzi (Illili Mahrour, 2019). 
This Zenata word iyamawen, is the plural of a yam whose root is $\Gamma R M$, and the verb yerrem, which means "build a stone wall" (Bounfour, Boumalek, 2001) refers to the stone-fortified structures that composed the inhabited space in this Saharan region. In the Gourara Zenata language, the letter " $r$ " is not pronounced (BaudotLamotte, 1964; Mammeri, 1984-2003; Bellil, 2002), so the word arrem or taghremt commonly used in toponyms to identify the Saharan fortresses and the vernacular human settlements is here pronounced aram for a single fortification, iyamine for two and iyamawen when they are many. Here, instead of just using the common arabic word ksar, a singular word meaning castle and always used to name a Saharan human settlement, Taguelzi inhabitants by using this composed toponym "Taguelzi I $\gamma$ amawen" highlight the duality of the historical event and the materiality of all the fortifications gathered there.

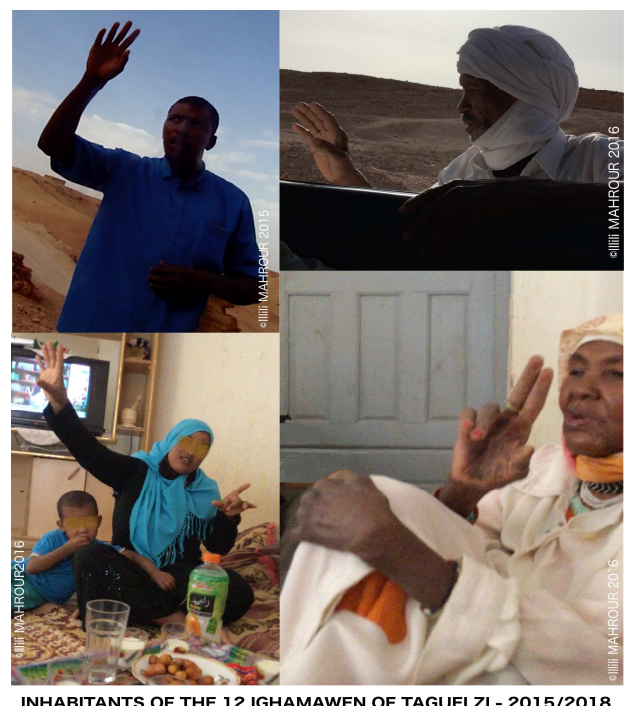

Fig. 7. Taguelzi inhabitants. (Illili Mahrour, 2018).

Furthermore, the other toponyms refer to the myth of a king who came with his servants to seek refuge but he feared to settle in every site, like in igguenannay which means hurtling, because he could have hurtled down the ravine. Samely in tagharasst, meaning "cutthroats", he was scared of being slaughtered by its dwellers... out of fear he moved on and on until he left. Through legends and myths the fortifications toponyms survived and allowed the fortified ruins to remain alive for the young generations and to maintain the memory of Taguelzi whole inhabited territory. Unfortunately, today Taguelzi vernacular architecture is ruined and its inhabitants moved out of the fortification and the palm grove dwellings to build concrete houses after the devastating floods in 2004, 2008 and 2014 called the nekbates. In emergency, they settled on the plateau overlooking the palm grove and built in concrete all the new houses, two mosques, a primary school and sports field. In this context, Taguelzi new urbanization extends in total break with the vernacular space organisation based on the iyamawen .

However, despite an advanced state of ruin, these ancient fortresses are still used according to different cultural and religious practices called Oua'dates, which maintain, year after year, a strong connection with place, time and space.

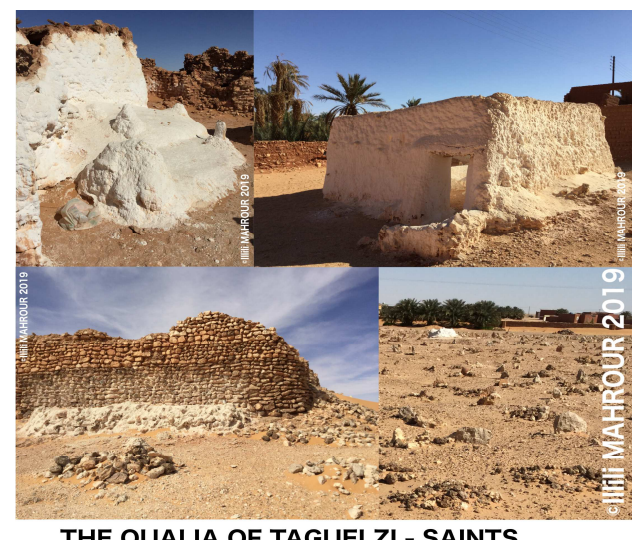

THE OUALIA OF TAGUELZI - SAINTS

Fig. 8. Taguelzi saint's: At Moussa Ouhammou, Sidi Moussa, El Ouali n'Tlat, Ba El Hadj Moussa (Illili Mahrour, 2019).

Taguelzi saints' celebrations start with Saint Sidi Moussa celebrated near the old mosque (8th Ramadhan), then Saint At Baba El Hadj Moussa, known as $\mathrm{Ba}$ El Hadj Moussa Koulou (17 Ramadhan) and last Saint El Ouali n'Telat. Inhabitants celebrate Moulay Abdallah too, the Saint of the Asfaou ksar situated $10 \mathrm{~km}$ from Taguelzi (from $3^{\text {rd }}$ to $27^{\text {th }}$ Achoura month). The dwellers consider the saints as their own saints, 
who do not belong to the Gourara major saints, as they are celebrated every year during several days by the licking of their graves, reading the Koran, welcoming and feeding guests with special dishes, declaiming the Ahellil poems with singing and dancing.

\subsection{Taguelzi fourteen fortresses}

Taguelzi is identified by its dwellers as "the twelve iramawen" but in fact it is composed of fourteen clearly identified fortresses with their own stone defensive structures, over a more than $10 \mathrm{~km}^{2}$ territory. Inhabitants call them ijennayin because of their overhanging defensive position.

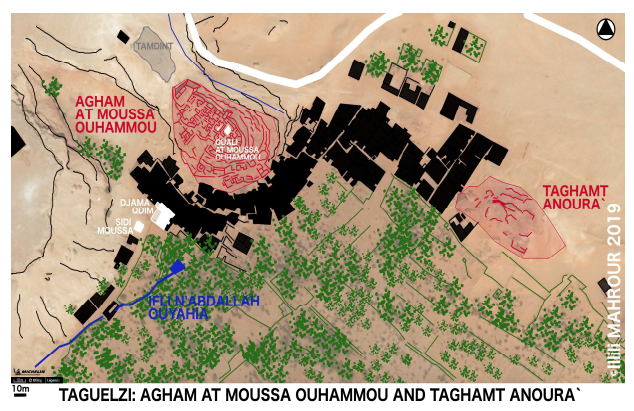

Fig. 9. Fortresses of Agham At Moussa Ouhammou and Taghamt Anoura', Taguelzi (Illili Mahrour, 2019).

The first fortification is Agham At Moussa Ouhammou (AMO) (Fig. 2). It is certainly the most interesting defensive structure because it stretches on an about $4000 \mathrm{~m}^{2}$ surface in a spur position, on an about $30 \mathrm{~m}$ vertical drop. It is singled out by its defensive system complexity (towers and bastion-shaped extension), the interweaving of the inhabited fortress interior fabric, the high defensive walls with triangular loopholes and the many daheliz (troglodyte spaces) still used as attics or as rooms in high temperature periods and Ramadhan. The eponym uncovered mausoleum is centrally located and composed of Saint Sidi Moussa descendant's graves, not to be confused with Sidi Moussa Oulmessaoud, the main saint of the Gourara region. This fortress is the largest and probably the last one abandoned. At the end of the nineteenth century, before the French colonization, "Zenata Merabtin from the Oued Saoura, from Kerzaz, harratin and negroes, inhabited it. The houses, very close to each other were forming a continuous wall" (Deporter, 1890).

The second fortification is Taghamt Anoura' located just below at a distance of $200 \mathrm{~m}$. It is a small fortification in an advanced state of ruin characterized by its inner well dug in the rock with masonry walls.

Lemkoudas and Iggenannay are two totally ruined fortresses situated in the north east of Agham AMO but the inhabitants still refer to them thanks to the iflan (water system) still at use and the founding myth of its human settlement.

El Ouali n'Tlat is the $5^{\text {th }}$ fortification situated at about $730 \mathrm{~m}$ from Agham AMO in the north. It is characterized by the tomb of a saint leaned against the walls of the $30 \mathrm{~m}$ based stone defensive trapezoidal shaped enclosure.

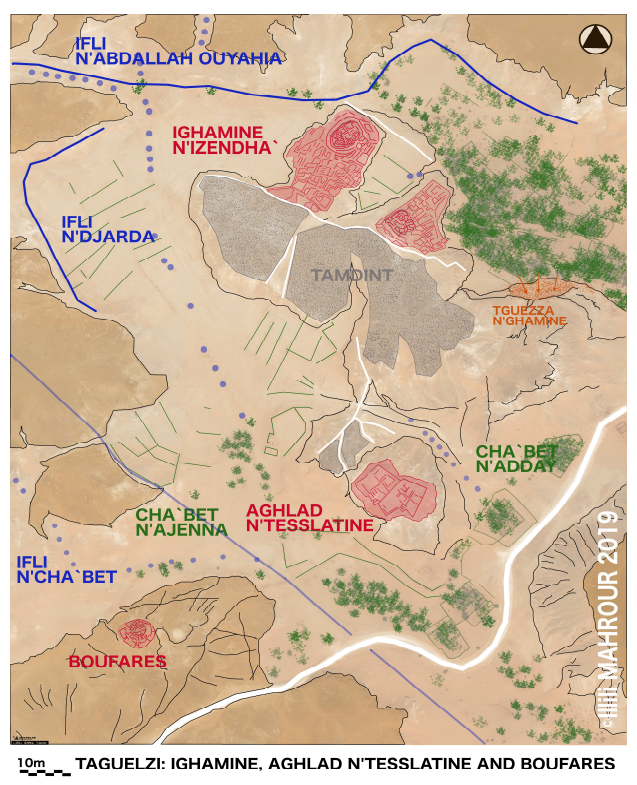

Fig. 10. Taguelzi inhabited space (Illili Mahrour, 2019).

Agham n'Boua liten, is the $6^{\text {th }}$ fortification situated south of Agham AMO on the edge of the cornice. It refers to the Bou Ali family descendants and is characterized by its ruined fortification walls, towers and its troglodyte part still reachable from the ravine walls (Fig. 6).

Ighamine includes the $7^{\text {th }}$ and the $8^{\text {th }}$ fortresses and the biggest is called Izendha`. They are 
characterized by the stone constructive technic of the enclosure walls. The successive floods have removed the urban fabric of the dwellings that were outside the defensive walls. During our field surveys, we were able to clearly identify the ditch, the wells and the double walled enclosure of stone structures.

Ighamine refers also to the area formed at the intersection of small ravines where Taguelzi main Iflan cross. This relief configuration reveals two places called "Cha'bet n'Ejenna" and "Cha'bet n'adday" correspondingly "the upper ravine" and the "lower ravine". Within the same area, there is "Teggezza n'Ghamine", which is a large cave formed by the extraction of clays for years.

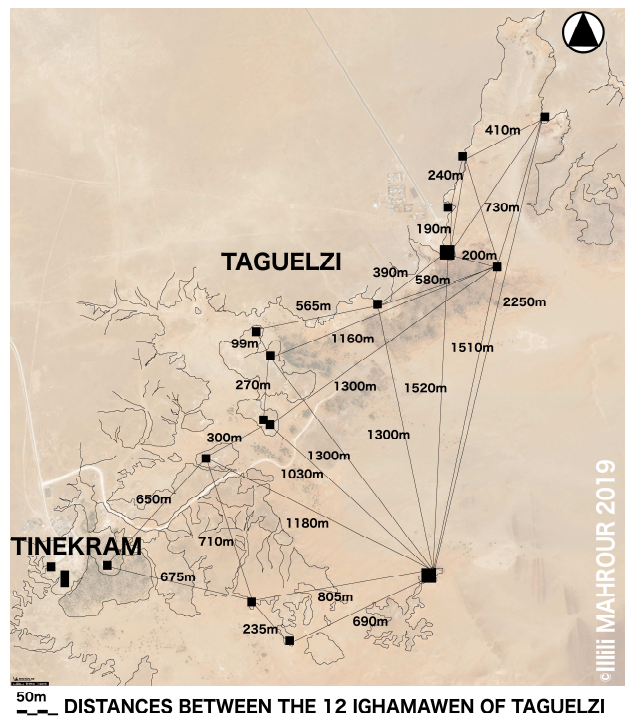

Fig.11. The distances between the 14 fortresses, Taguelzi (Illili Mahrour, 2019).

Aghlad n'Tesslatine is the $10^{\text {th }}$ Taguelzi fortification composed of two adjoining fortified enclosures (60 m x80 m floor space). The legend and the toponym Tesslatine refer to "two brides" to whom these fortifications were built. They are separated from Ighamine n'Izendha` by large open cemeteries overlooking the fortified structures and spread over large areas adjacent to the fortifications. A graveyard is called tamedint and refers to the place where timedhline (the graves) are gathered. As a rule, the warriors were buried where they fell. Moreover, we note that in Arabic the word means "city", probably an allusion to "the city of the dead" facing "the city of the living". This duality is often found in the composition of the inhabited space of the ighamawen.

Boufares is the $11^{\text {th }}$ fortification facing Aghlad n'Tesslatine and Ighamine named according to the ordinary family name Boufares which refers to a "horseman" or a "noble rider" and evokes a rich noble background. It is about $35 \mathrm{~m}$ in diameter round shaped.

Azidi' are the $12^{\text {th }}$ and the $13^{\text {th }}$ fortifications south of Boufares, ahead of all Taguelzi fortifications and neighbouring Tinkram (Fig. 4).

Tagharast is the $14^{\text {th }}$ and the last most unexpected Taguelzi fortress. It is built on an isolated promontory at more than $10 \mathrm{~m}$ from the ground. We notice vestiges of an ancient well, caves and daheliz too.

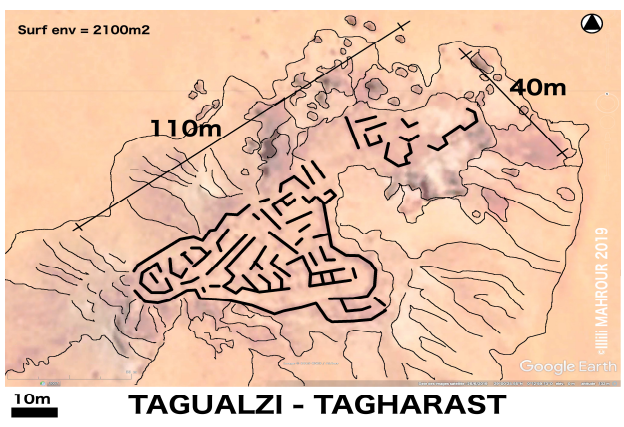

Fig. 12. Tagharast fortress (Illili Mahrour, 2019).

\subsection{The defensive stonewalls constructive technique}

The twelve fortresses are distinguished by the technical quality of their stoned fortified walls. The flat shape of the Ouled Aïssa Hmada edge led the building masters to dig the fortresses moat by trenching the silicified limestone slab which allowed them to erect defensive towers either circular, as in Izendha' fortress, or square, as in Agham At Moussa Ouhammou (Fig. 2).

The architectonic of walls is based on the constructive know-how of building stonewalls with sandstone, "El Hadjra" and limestone, "El Tafza". The technique consists in alternating large and small stones on both the length and the width of the walls. In addition, the wall plaster and the stone joints are realized with the re- 
moved layers of sand and pure clay, "El Thine" from the area "Teghezza n'Ighamine". The set of stone layers in AMO and Ighamine n'Izendha' are fairly regular and deploy on heights exceeding 35 cubits high. They are distinguished by a variety of techniques ranging from the cyclopean masonry to tight and regular layers, which need series of precise rounded buttresses made of stones stages assemblages to counterweight the pushing high walls (Fig. 13). The three fortresses of Agham At Moussa Ouhammou and Ighamine n'Izendha' contain cyclopean masonry in their enclosure walls and corner towers bonding.

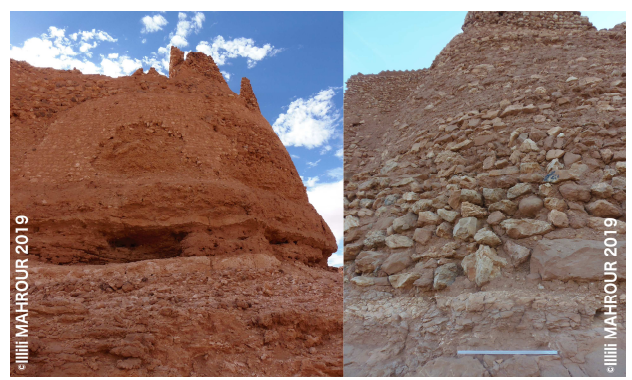

Fig. 13. Defensive stone walls constructive details (Ighamine and Agham AMO) (Illili Mahrour, 2018).

\section{Conclusion}

In this research on built heritage, without our anthropological approach focused on a close work with the inhabitants we would never have imagined that Taguelzi was composed of fourteen fortresses. By observing the fortresses ruins, questioning the languages in use and the legends we have been able to apprehend the place practices by addressing the construction issue through the act of building. Today, observing the inhabited space practices enables us to read the building acts mutations that replace the original stone architecture know-how by an empirical use of concrete. Here, Taguelzi inhabited space is built between "dead ruins" and "alive ruins" where the architecture and the anthropology of space complete each other to reveal the living relationship to place and time.

\section{Note}

Our maps are drawn using our surveys and as background a satellite pictures photomontage of several screenshots provided by Google Earth or www.michelin.fr website.

\section{Bibliography}

Bellil, R. (2003). Ksour et saints du Gourara. Dans la tradition orale, l'hagiographie et les chroniques locales. Mémoires du Centre National de Recherches Préhistoriques Anthropologiques et Historiques, Nouvelle Série n³, Alger.

Bisson J. (1957). Le Gourara, étude de géographie humaine, Institut de Recherche Saharienne, Mémoire nº 3, France.

Bisson, J.; Jarir, M. (2002). "Ksour du Gourara et du Tafilelt. De l'ouverture de la société oasienne à la fermeture de la maison”, in Baduel, P.R., dir., Habitat, État, société au Maghreb. Nouvelle édition, (on-line), CNRS Éditions, Paris.

Boudot-Lamotte, A. (1964). Notes ethnographiques et linguistiques sur le parler Berbère de Timimoun, Extrait du Journal Asiatique, Imprimerie Nationale, Paris.

Bounfour, A.; Bounmalk A. (2001). Vocabulaire usuel du tachelhit: tachelhit-français, Centre Tarik ibn Zyad, Rabat.

De Colomb. (1860). Les Oasis du Sahara et les routes qui y conduisent, Archives d'Outre-Mer, Aix en Provence, Algérie, Gouvernement Général Algérie, 4H/2, Carton 4H1 à 4, Manuscrit, 272 pp.

Deporter, V. (1890). A propos du Transsaharien: Extrême-sud de l'Algérie, (le Gourara, le Touat, In-Salah, le Tidikelt, le pays des Touareg-Hoggar, l'Adrar, Tin Bouctou, Agadès), 1888-1889, Imprimerie. de P. Fontana et compagnie, Alger.

Laureano, P. (1991). Sahara, jardin méconnu, Editions Larousse, Paris.

Mahrour, K. (1992). La mémoire collective d'une cité du Désert : Timimoun, Ecole Polytechnique d'Architecture et d'Urbanisme Ed., Alger.

Mammeri, M. (2003). L'ahellil du Gourara, Nouvelle série n¹, Mémoires du Centre National de Recherches Préhistoriques, Anthropologiques et Historiques, Alger.

Martin, A.G.P. (1923). Quatre siècles d'histoire marocaine. Au Sahara de 1504 à 1902. Au Maroc de 1894 à 1912 , D'après archives et documentations indigènes, Librairie Félix Alcan, Paris.

Villanova, R. De; Duarte, C.R. (2012). Nouveaux regards sur l'habiter, Outils et méthodes, de l'architecture aux sciences sociales, Le Manuscrit. 